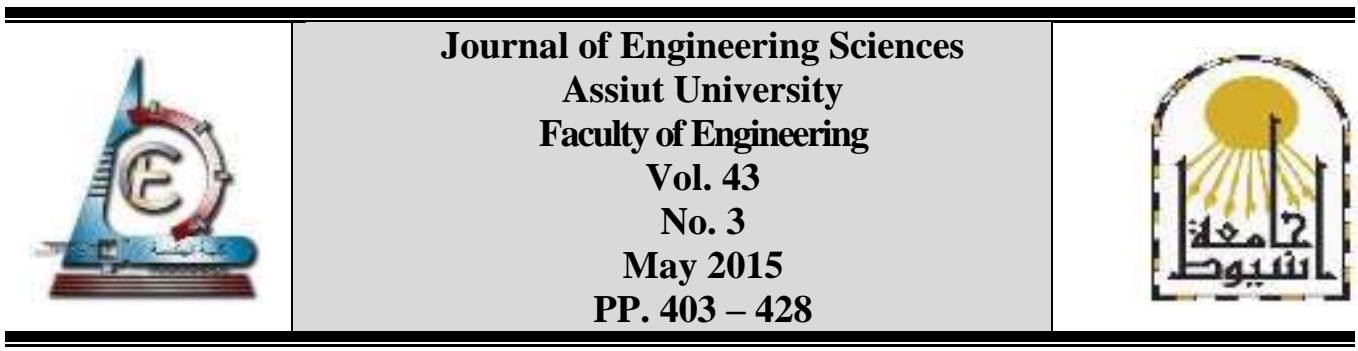

\title{
ANALYZING ORGANIZATIONAL STRUCTURE FOR CONTRACTING FIRMS' OF CLASSIFICATION "A", EGYPT
}

\author{
Mahmoud A. Zaki ${ }^{1}$, Hesham S. Hussien ${ }^{2}$, \\ Haytham M. Sanad ${ }^{3}$, Sara S. El-Khoriby ${ }^{4, *}$ \\ 1, 3, 4 Architecture Dept., Faculty of Engineering, Tanta University \\ ${ }^{2}$ Architecture Dept., Faculty of Engineering, Cairo University
}

(Received 9 March 2015; Revised 28 March 2015; Accepted 12 May 2015)

\begin{abstract}
The present study is an attempt to address the efficiency and performance of construction companies in Egypt. This study highlights and compares different types of organizational structures of contracting firms of classification "A". Comparison covers Functional, Divisional and Matrix organizational structures. It analyses and evaluates the effect of the organizational structure on the contracting companies' performance and success. Restrictions of contracting firms of classification "A" according to EFCBC (Egyptian Federation for Construction and Building Contractors) on companies' performance are investigated. Seven main contracting firms of classification "A" representing private, business and public sectors are considered in the present field survey. The field study is conducted by using survey questionnaire, personal interviews for the companies' employees and formal data from the selected companies. Obtained results show that the organizational structure operates in its highest efficiency when hiring minimum number of most qualified personnel. Moreover, avoiding centralization i.e. routine; bureaucracy and long paper work have a significant impact. This research confirmed the domination of functional organization structure in Egyptian companies. The study concludes that a composite structure between matrix and functional organizational structure based on (geographical location or project type), may be recommended as the optimal organizational structure for contracting firms of class "A" in Egypt.
\end{abstract}

Keywords: Organizational structure, contracting firms, Egypt, matrix structure, construction, management, performance.

* Corresponding author.

E-mail address:sarasaher87@yahoo.com 
Sara S. El-Khoriby, et al., analyzing organizational structure for contracting firms' of ............

\section{Introduction}

Recently, construction industry in Egypt has been facing serious challenges and significant obstacles due to political instability. Numerous investigations were performed to address the industry's current ways to restore it. Management science applications are certainly one of the most dominant topics in optimizing studies. Business optimization aims to maximize profit in such a way that companies have to adjust and reorganize their strategies and organizational structures to cope with threats. The primary challenge of project management in construction companies is to achieve all of the project goals and objectives while honoring the preconceived constraints. The primary constraints are scope, time, quality and budget. Also, it has to comply with sustainability, insurance, health, safety, and legal requirements of the country in which the project is based. Wolf (2002) [1], stated that structure has a direct effect on the success of an organization operational strategy. "Good organization structure influences the execution behaviors of a company. Structure not only shapes the competence of the organization, but also the processes that shape performance".

\section{Objective of the study}

Three years ago, according to EFCBC documents 28,000 firm were registered working contracting firms. Lately, it recorded 11,000 firms registered, with only 3,000 firms which are actually working in the market. Also, more than $75 \%$ of the contracting firms in Egypt had to liquidate or change their business. Egyptian contracting firms are currently, facing many challenges to achieve their projects' goal which causes great loss in the share capital, profit or manpower. The hierarchy of the management work flow affects the project work in different ways. In addition, the organization's corporate culture and communication channels between the organization different departments have a significant effect. Using the most feasible structure for each organization may increase its efficiency and thus increase its share capital and profit utilizing minimum manpower. Hence, the present study aims at:

1) Presenting different types of organizational structures.

2) Addressing the role of the management hierarchy in the organization and its effect on the share capital, profit and manpower effort.

3) Monitoring field realistic observations and measurements of the current situation for organizational structure of chosen contracting firms.

4) Deducing the optimal qualified work flow to be recommended in contracting firms' class "A" based on the study.

\section{Literature review}

There are many different opinions and definitions on organizational structure. Walton (1986) [2] tied structure to effectiveness, asserting that management restructuring is designed to increase not only the efficiency but also the effectiveness of the management organization. Mintzberg (1983) [3], says that Organizational structure defines how individuals and groups are organized or how their tasks are divided and coordinated. He defines the organizational structure as; "...the sum of total in which its labour is divided into distinct tasks and then its coordination is achieved among these tasks." There is no 
such thing as a best organizational structure. E.C. Ubani (2012) [4], stated that organizational structure is the management framework adopted to oversee the various activities of a construction project or other activities of an organization. A suitable organizational structure assists the project management team to achieve high performance in the project through gains in efficiency and effectiveness. Tran \& Tian (2013) [5], regarding the purpose of the organization's founding, they can be described as successful (profitable) or failure (non- profitable) ones. To achieve these goals organizations create inner order and relations among organizational parts, that can be described as organizational structure. D. Wolf 2002 [1], says that in an- other sense, "structure is the architecture of business competence, leadership, talent, functional relationships and arrangement. Underdown (2012) [6], said that organizational structure "is the formal system of task and reporting relationships that controls, coordinates, and motivates employees so that they cooperate to achieve an organization's goals". Ganesh 2013 [8], the manager determines the work activities to get the job done, writes job descriptions, and organizes people into groups and assigns them to superiors. He fixes goals and deadlines and establishes standards of performance. Operations are controlled through a reporting system. The whole structure takes the shape of a pyramid. The structural organization implies the following things:

a. The formal relationships with well-defined duties and responsibilities;

b. The hierarchical relationships between superior and subordinates within the organization;

c. The tasks or activities assigned to different persons and the departments;

d. Coordination of the various tasks and activities;

e. A set of policies, procedures, standards and methods of evaluation of performance which are formulated to guide the people and their activities.

\subsection{Classification of organizational structures' types}

Montana and Charnov (1993) [7], stated that the primary formal relationships for organizing, as discussed earlier, are responsibility, authority, and accountability. They enable us to bring together functions, people, and other resources for the purpose of achieving objectives. The framework for organizing these formal relationships is known as the organizational structure. It provides the means for clarifying and communicating the lines of responsibility, authority, and accountability. Thus, Organization management structures can be classified into four major structures as shown in Fig (1).

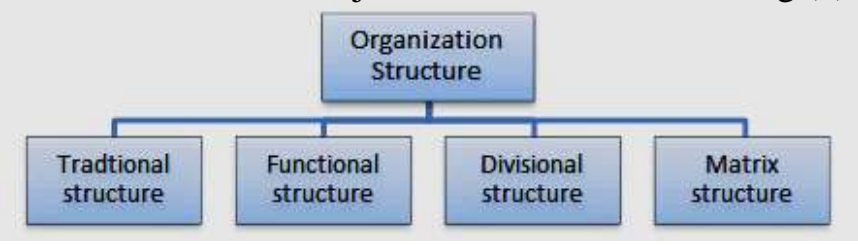

Fig. 1. Types of organizational structure

\section{1) Traditional structure:}

This type was satisfactory fifty years ago, when companies had only one or two product lines for organization control and conflicts were minimal. Fig (2) shows an example for the traditional organizational structure for a construction company. 
Sara S. El-Khoriby, et al., analyzing organizational structure for contracting firms' of ............

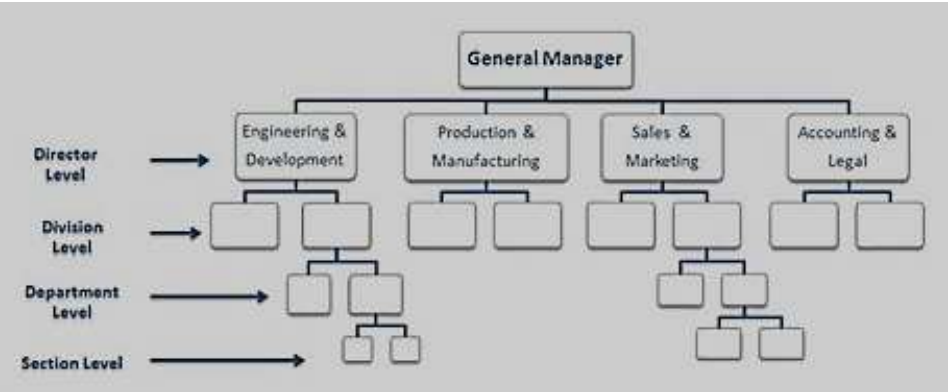

Fig. 2. Traditional organizational structure example, Ganesh 2013 [8]

With the growth of project management and the passing of time, executives began to realize problems of this structure. Table (1) illustrates the advantages and disadvantages of this type, Ganesh 2013 [8]. Newer forms of structures had to be innovated and developed such as functional, divisional and matrix management structures.

\section{Table 1.}

Advantages and disadvantages of Tradiotional Organizal structure Ganesh 2013 [8]

\begin{tabular}{|l|l|}
\hline \multicolumn{1}{|c|}{ Advantages } & \multicolumn{1}{c|}{ Disadvantages } \\
\hline Team easier budgeting and cost control are possible. & No one is directly responsible for the total project. \\
\hline $\begin{array}{l}\text { Quick reaction capability exists, but may be dependent } \\
\text { upon the priorities of the functional managers. }\end{array}$ & $\begin{array}{l}\text { Does not provide the project-oriented emphasis } \\
\text { necessary to accomplish the project tasks. }\end{array}$ \\
\hline $\begin{array}{l}\text { Continuity in the functional disciplines; policies, } \\
\text { procedures, and lines of responsibility are easily } \\
\text { defined and understandable. }\end{array}$ & $\begin{array}{l}\text { Coordination becomes complex, and additional } \\
\text { lead time is required for approval of decision. }\end{array}$ \\
\hline $\begin{array}{l}\text { Good control on personnel, since each } \\
\text { employee has only one person to report to. }\end{array}$ & $\begin{array}{l}\text { Ideas tend to be functionally oriented with } \\
\text { little regard for ongoing projects. }\end{array}$ \\
\hline
\end{tabular}

\section{2) Functional structures:}

The design implies that employees are grouped according to their specialties as shown in Fig (3), Ganesh (2013) [14].

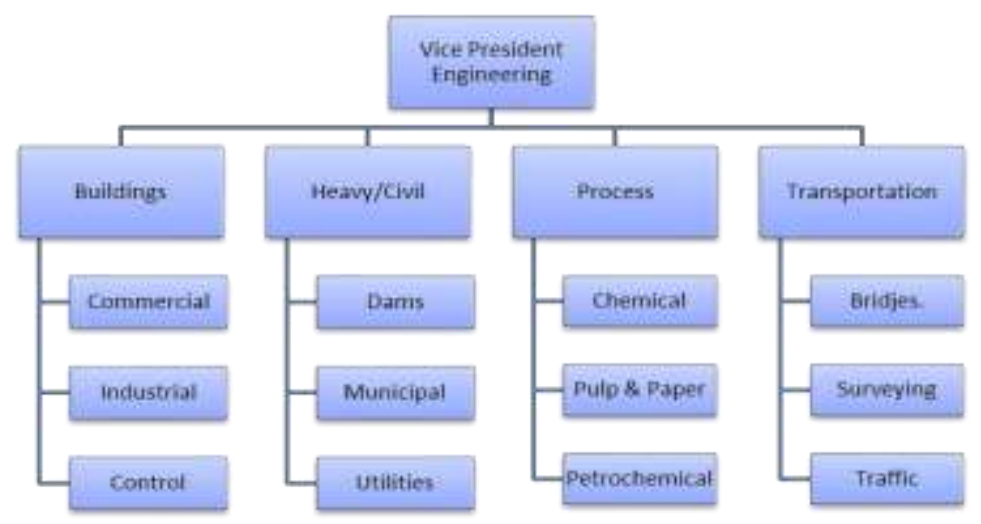

Fig. 3. Funtional organizational structure for a construction company example Ganesh 2013 [8]

Functional structures work more efficiently under certain conditions. Such as, the organization has well-developed products or services and implemented sets of 
407

JES, Assiut University, Faculty of Engineering, Vol. 43, No. 3, May 2015, pp. 403 - 428

coordinating mechanisms. Also, if the organization is small or medium-sized. Table (2) illustrates the advantages and disadvantages of this type, Ganesh 2013 [8].

Table 2 .

The advantages and disadvantages of Functional organizational structure Ganesh 2013[8]

\begin{tabular}{|l|l|}
\hline \multicolumn{1}{|c|}{ Advantages } & \multicolumn{1}{|c|}{ Disadvantages } \\
\hline $\begin{array}{l}\text { Team members work in groups according } \\
\text { to their functional specialties and expertise. }\end{array}$ & $\begin{array}{l}\text { The barriers due to the differences in goals and } \\
\text { processes between functions can prevent } \\
\text { functions working together on projects. }\end{array}$ \\
\hline $\begin{array}{l}\text { Career advancement for functional team members } \\
\text { within the functional area is possible when they show } \\
\text { improved morale and productivity. }\end{array}$ & $\begin{array}{l}\text { The competition between functions may arise for } \\
\text { shared resources resulting in conflicts between them. }\end{array}$ \\
\hline $\begin{array}{l}\text { Better communications due to vertical and } \\
\text { well-established channels }\end{array}$ & $\begin{array}{l}\text { Some of the decisions from upper management } \\
\text { may favor the strongest and loudest groups. }\end{array}$ \\
\hline $\begin{array}{l}\text { Flexibility to use any of the resources as } \\
\text { and when needed for projects }\end{array}$ & $\begin{array}{l}\text { In multi-group project situations, there will be } \\
\text { difficulty in establishing authority and responsibility. }\end{array}$ \\
\hline $\begin{array}{l}\text { Functional managers maintain absolute } \\
\text { control over budget and have authority, and } \\
\text { therefore projects may be completed within } \\
\text { allocated budget and schedule. }\end{array}$ & $\begin{array}{l}\text { Functional form becomes inflexible and costly to } \\
\text { operate when the no. of products offered becomes } \\
\text { too many or if scheduling becomes a problem. }\end{array}$ \\
\hline
\end{tabular}

\section{3) Divisional structure:}

Is a type of grouping employees according to either a product or a project and can be extended to a geographical location or based on customers as shown in Figures (4) and (5).

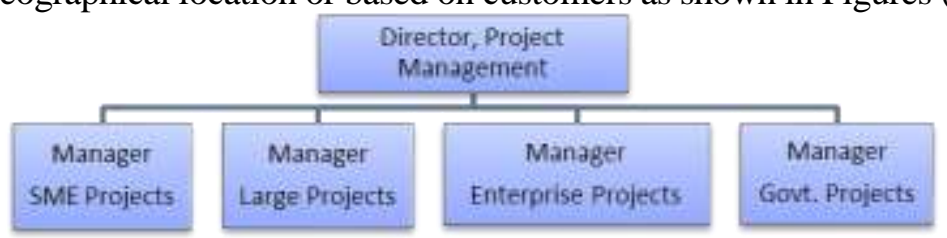

Fig. 4. Divisional organizational structure based on Project example Ganesh 2013 [8]

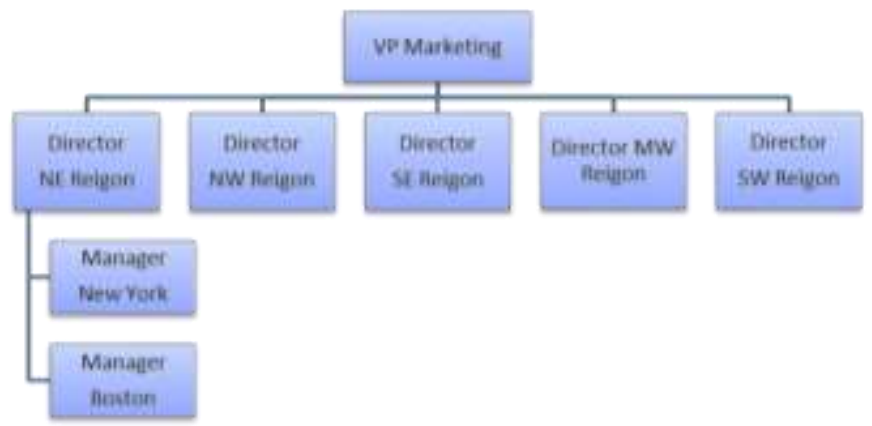

Fig. 5. Divisional organizational structure based on Geographical location example Ganesh 2013 [8]

Divisional structure works better under these conditions: organizations require projects that are based on a particular product or service; specialized knowledge is needed; projects demands better services for different types of markets. Table (3) illustrates the advantages and disadvantages of this type Ganesh 2013 [8]. 
Sara S. El-Khoriby, et al., analyzing organizational structure for contracting firms' of ............

Table 3.

Advantages and Disadvantages of Divisional organizational structure

\begin{tabular}{|l|l|}
\hline \multicolumn{1}{|c|}{ Advantages } & \multicolumn{1}{|c|}{ Disadvantages } \\
\hline $\begin{array}{l}\text { Organizations differentiate and focus on } \\
\text { products, customers, locations or projects } \\
\text { thereby enabling them to address various issues } \\
\text { and impacts caused by their individual needs. }\end{array}$ & $\begin{array}{l}\text { Too much focus on an existing product may } \\
\text { cause individuals not to keep with technology } \\
\text { advances in their own field. }\end{array}$ \\
\hline $\begin{array}{l}\text { Due to their focus and close proximity to } \\
\text { issues, project teams have better } \\
\text { understanding of specific needs. }\end{array}$ & $\begin{array}{l}\text { Lack of opportunities to share new advances } \\
\text { and technology between groups. }\end{array}$ \\
\hline $\begin{array}{l}\text { Team members respond quickly to changes } \\
\text { that affect product, customer or location. }\end{array}$ & $\begin{array}{l}\text { There may be a duplication of efforts and } \\
\text { therefore increases in costs. }\end{array}$ \\
\hline $\begin{array}{l}\text { Unprofitable products or projects can be } \\
\text { easily recognized and eliminated. }\end{array}$ & $\begin{array}{l}\text { Instability of employees if projects are } \\
\text { terminated. }\end{array}$ \\
\hline
\end{tabular}

\section{4) Matrix structure:}

Fig (5) shows an example of matrix organizational structure of a construction company. Table (4) illustrates the advantages and disadvantages of this type Ganesh 2013 [8].

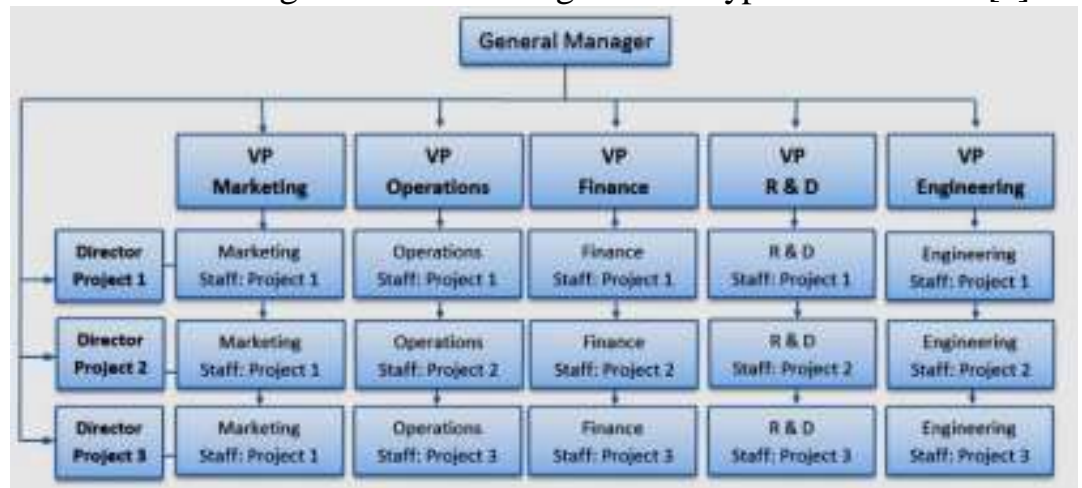

Fig. 6. Matrix organizational structure of a construction company example Ganesh 2013 [8]

\section{Table 4}

Advantages and Disadvantages of Matrix organizational structure

\begin{tabular}{|l|l|}
\hline \multicolumn{1}{|c|}{ Advantages } & \multicolumn{1}{|c|}{ Disadvantages } \\
\hline $\begin{array}{l}\text { Takes advantage of both the function and the } \\
\text { project or the department structures leading } \\
\text { to flexibility in responding to changes; }\end{array}$ & $\begin{array}{l}\text { Employees reporting to dual supervisors } \\
\text { may run into potential conflict during } \\
\text { allocation to projects and evaluation }\end{array}$ \\
\hline $\begin{array}{l}\text { Decision making process becomes simplified due } \\
\text { to authority thus, Budgeting and staffing for } \\
\text { projects become easy to create and manage }\end{array}$ & $\begin{array}{l}\text { Duplication of efforts may arise if } \\
\text { communication fails between projects }\end{array}$ \\
\hline $\begin{array}{l}\text { Team members of a project have accountability } \\
\text { for project deliverables and performance }\end{array}$ & $\begin{array}{l}\text { The best available human resources may end } \\
\text { up with higher-priority projects }\end{array}$ \\
\hline $\begin{array}{l}\text { Processes can be tailored for individual projects } \\
\text { provided there are no conflicts with general } \\
\text { organizational policies and procedures }\end{array}$ & $\begin{array}{l}\text { Shifting team members between projects } \\
\text { may hinder their growth and development in } \\
\text { their specialized areas }\end{array}$ \\
\hline $\begin{array}{l}\text { New project or functional teams can develop } \\
\text { out of necessity }\end{array}$ & $\begin{array}{l}\text { Lessons learned on projects may not be } \\
\text { communicated to other new or existing projects }\end{array}$ \\
\hline
\end{tabular}




\subsection{Organizational structure selection influence on firm efficiency}

D. Wolf 2002 [1], stated that structure has a direct effect on the success of an organization operational strategy. "Good organization structure influences the execution behaviors of a company. Structure not only shapes the competence of the organization, but also the processes that shape performance". Clemmer 2003[16], supported the idea that organizational structure shapes performance: Good performers, in a poorly designed structure, will take on the shape of the structure. Many organizations induced learned helplessness. People in them become victims of "the system". This often comes from a sense of having little or no control over their work processes, policies and procedures, technology, support systems and the like. These feelings are often amplified by a performance management system that arbitrarily punishes people for behaving like the system, structure or processes they have been forced into. Penguin 2003 [9], claimed that organizational effectiveness and its relation to structure is determined by a fit between information processing requirements so people have neither too little nor too much irrelevant information. However, the flow of information is essential to an organization's success. Also Germaina 2008 [10], studied the effect of structure on the performance mediating supply chain management and found that in stable environment, formal structure has a positive effect on the performance while in dynamic atmosphere negative effect is attained.

Moreover, Chen and Huang 2007 [11], claimed that decentralized and informal structure will lead to higher performance. Winfred 2011 [12], A suitable organizational structure may assist the project management team to achieve high performance in the project through gains in efficiency and effectiveness. Specific project objectives are set to be achieved at the end of each project. A study carried out by Yinghui and Cheng Eng. (2004) [13], on the "impact of organizational structure on project performance" was limited to site organizational structure. The study considers it necessary to carry out a comprehensive analysis of organizational structure in order to ascertain the effects of various variables in the structure on the effective delivery of civil engineering projects

\section{Research methodology}

The present study is based on a case study approach. The study used questionnaire survey forms as the main approach, along with interviews based on semi-questionnaire and formal data collected from the selected companies. The questionnaire survey was distributed to the selected respondents (Total 79 respondent). A total of seven Egyptian contracting companies of classification "A" according to EFCBC are considered in the present study during 2014. These companies in the survey cover: public sector $(\mathrm{C} 1$, $\mathrm{C} 2)$; private $(\mathrm{C} 3, \mathrm{C} 4, \mathrm{C} 7)$ and business sectors $(\mathrm{C} 5, \mathrm{C} 6)$, which have strong presence in the labor market. Both qualitative and quantitative approaches are employed in this study to assess the effect of organizational structure on companies' performance.

\subsection{Data collection \& respondent background}

From the analysis of the questionnaire, the majority of respondents were universityeducated (87\%), $13 \%$ of them had an average qualification. Most of the respondents were male (80\%), and just (20\%) female. The average age of the respondents was almost 40 years, with average years of experience $(6-10)$ as a senior engineer, 15 years as a 
Sara S. El-Khoriby, et al., analyzing organizational structure for contracting firms' of ............

project manager. Various methods were used to reach the respondents such as: personal interviews; group or focus interviews; mailed questionnaires \& telephone interviews.

\subsection{Questionnaire design}

The questionnaire in the present study follows questionnaires designed in references Cheung, Peter Wong, Lam (2012) [14] and Samuel Sidumedi (2002) [15]. The questionnaire consists of 60 main questions divided into eleven main groups of questions covering the following areas: (A)Organization Strategy, Mission \& Values; (B) Managers Performance \& Responsibilities; (C) Employees Performance \& Satisfaction; (D) Dataflow Evaluation; (E) Reporting Process Evaluation; Innovation \& Training Enhancement; (G) Organization Financial Performance; $(\mathrm{H})$ Internal Business Process; (I) Research \& Development Process; (J) Risk Management Awareness; (K) Client/Customer Satisfaction. The present oriented method developed involved the use of the Likert scaling as follows: One for totally agree; Two for Agree; Three for Neutral; Four for Disagree; Five for totally disagree. The results collected in the questionnaire are statically analyzed using one way ANOVA Test at 5\% level of significance, and represented graphically using bar charts.

\section{Case studies}

Contracting companies of classification "A" were specifically selected for several reasons. First, this type of companies has well known organizational structure that can be easily studied and analyzed. Second, contracting companies cover many aspects according to different levels of performance efficiency, based on their financial progress reports. Third and finally, the selected companies were willing to participate and conduct in this survey offering all formal data required.

Table (5) illustrates the basic data of the survey samples. Data shown in Table (5) are collected through: companies' website; empirical data from the companies' departments.

5.1. Case (1): C1: Arab Contractors Co. "Middle \& West of Delta" \& Case (2): C2: Arab Contractors Co. "North \& East of Delta"

The Arab Contractors (AC) is one of the leading construction companies in the Middle East and Africa. With 77,000 employees work in collaboration with customers, partners, and suppliers in more than 29 countries [17]. Fig (7) shows the company's organizational structure "Mixture between Functional \& Divisional structure (based on location)".

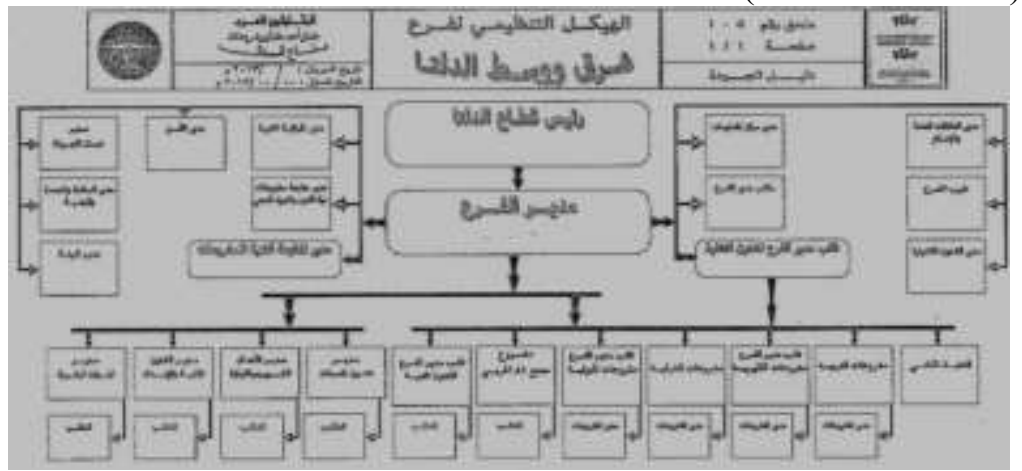

Fig. 7. Arab Contractor's Co. organizational structure 


\section{Table 5.}

Basic data of the selected companies (By: Author)

\begin{tabular}{|c|c|c|c|c|c|c|c|c|c|}
\hline No & Company name & Sector & $\begin{array}{l}\text { Organizational } \\
\text { Structure type }\end{array}$ & $\begin{array}{l}\text { Man } \\
\text { power }\end{array}$ & Company Activities & $\begin{array}{l}\text { Company } \\
\text { Capital }\end{array}$ & $\begin{array}{l}\text { No. of } \\
\text { Surveys } \\
\text { Received }\end{array}$ & $\begin{array}{l}\text { No. of } \\
\text { Surveys } \\
\text { Delivered }\end{array}$ & $\begin{array}{l}\text { No. of } \\
\text { Surveys } \\
\text { Eliminated }\end{array}$ \\
\hline C1 & $\begin{array}{l}\text { Arab Contractors Co. } \\
\text { "Middle \& West of Delta" }\end{array}$ & Public & \multirow{2}{*}{$\begin{array}{l}\text { Mixed between } \\
\text { Functional \& } \\
\text { matrix structure }\end{array}$} & 77,000 & \multirow{2}{*}{$\begin{array}{l}\text { Services including: Public buildings, bridges, } \\
\text { roads, tunnels, airports, housing, water \& sewage } \\
\text { projects, wastewater treatment plants, power } \\
\text { stations, dams, hospitals, electromechanical } \\
\text { projects, engineering consultancy, ,...etc. }\end{array}$} & \multirow{2}{*}{$\begin{array}{l}8 \\
8 \\
8 \\
8 \\
8 \\
8 \\
8 \\
8 \\
\text { i }\end{array}$} & \multirow[t]{2}{*}{25} & 15 & 3 \\
\hline $\mathrm{C} 2$ & $\begin{array}{l}\text { Arab Contractors Co. } \\
\text { "North \& East of Delta" }\end{array}$ & Public & & & & & & 17 & 4 \\
\hline $\mathrm{C3}$ & Hossam \& El-Said Co. & Private & $\begin{array}{l}\text { Functional } \\
\text { structure }\end{array}$ & 40 & $\begin{array}{l}\text { Delivers housing, service and industrial projects } \\
\text { to the government. }\end{array}$ & $20,000,000$ & 20 & 10 & 2 \\
\hline C4 & Orascom Construction Co. & Private & Matrix structure & 40,000 & $\begin{array}{l}\text { Targets large industrial and infrastructure projects } \\
\text { principally, undertakes major commercial, } \\
\text { industrial and infrastructure projects and } \\
\text { institutional projects. }\end{array}$ & $5,000,000,00$ & 25 & 14 & 2 \\
\hline C5 & Egyptian Dredgers Co. & Business & $\begin{array}{l}\text { Functional } \\
\text { structure }\end{array}$ & 1100 & $\begin{array}{l}\text { Earth works of waterways, Establishment of fish } \\
\text { farms, Development of irrigation works, } \\
\text { Establishment of ports and marine works, shores } \\
\text { protection, Marine cable, laying, Roads leveling. }\end{array}$ & 守营山 & 25 & 14 & 2 \\
\hline C6 & Giza Co. & Business & $\begin{array}{l}\text { Mixed between } \\
\text { Functional \& } \\
\text { Divisional } \\
\text { structure (based } \\
\text { on location) }\end{array}$ & & $\begin{array}{l}\text { Contracting works and civil construction, utilities } \\
\text { and concrete works prefabricated housing of all } \\
\text { types and levels, hotels and hospitals and public } \\
\text { buildings }\end{array}$ & 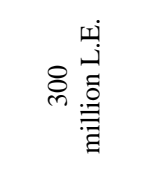 & 25 & 11 & 0 \\
\hline C7 & El-Swedy Electric Co. & Private & $\begin{array}{l}\text { Functional } \\
\text { structure }\end{array}$ & 50 & $\begin{array}{l}\text { Organization specialized in the supply, } \\
\text { installation and commissioning of overhead } \\
\text { transmission lines and substations on a turnkey } \\
\text { basis for utilities and industries. }\end{array}$ & n兽 & 20 & 10 & 1 \\
\hline
\end{tabular}




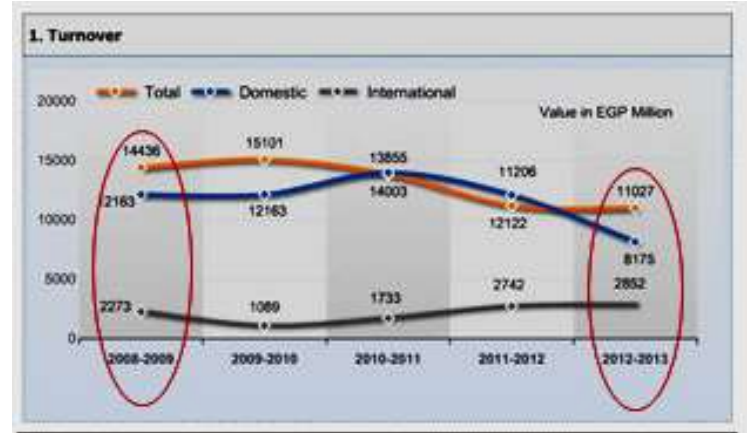

Fig. 8. Arab Contractor's Co. Financial situation 2008- 2013 diagram

Fig (8) illustrates the financial behavior of the company in the period 2008 to 2013 . It clearly shows a continuous decrease in the domestic aspect, while there is a noticeable increase in the international one.

\subsection{Case (3): C3: Hossam \& El-Said Co.}

Hossam \& El-Said Co. is one of the contracting companies in Egypt that realized the importance of the organizational structure's role in the company performance. So, it hired another institution that is specialized in evaluating and restructuring the companies' organizational structure. Fig (9) shows Hossam \& El-Said Co. original organizational structure "Functional structure" which had serious problems, such as authority centralization and the lake of essential departments. While, Fig (10) shows Hossam \& ElSaid Co. organizational structure "Mixture between functional and matrix structure" after modification. Specific job descriptions, job titles and other details are attached with the organizational structure, to assure it's going to operate efficiently.

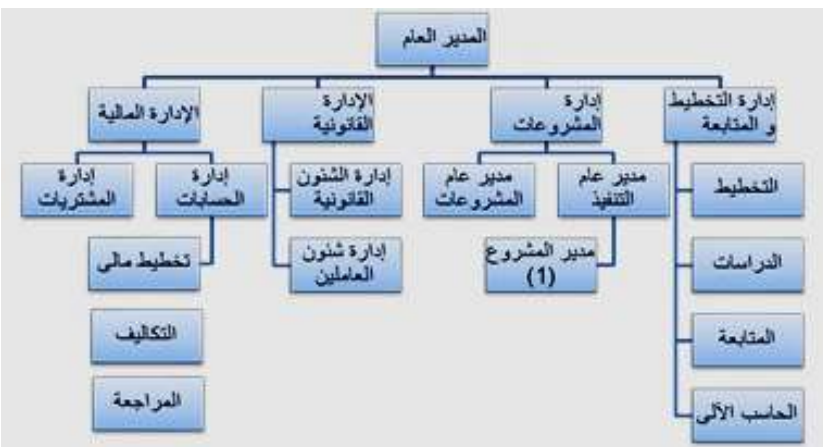

Fig. 9. Hossam \& El-Said Co. organizational structure (Original)

\subsection{Case (4): C4: Orascom Construction Co.}

Orascom Construction (OC) is an engineering and construction contractor primarily focused on infrastructure, industrial and high-end commercial projects in the Middle East, North Africa and the United States for public and private clients [18]. Orascom organizational structure is a mixture between functional and matrix organizational structure \{But it couldn't be displayed here for confidentiality reasons\}. Fig (11) shows a noticeable increase in the company's financial situation for years $2006-2011$. 


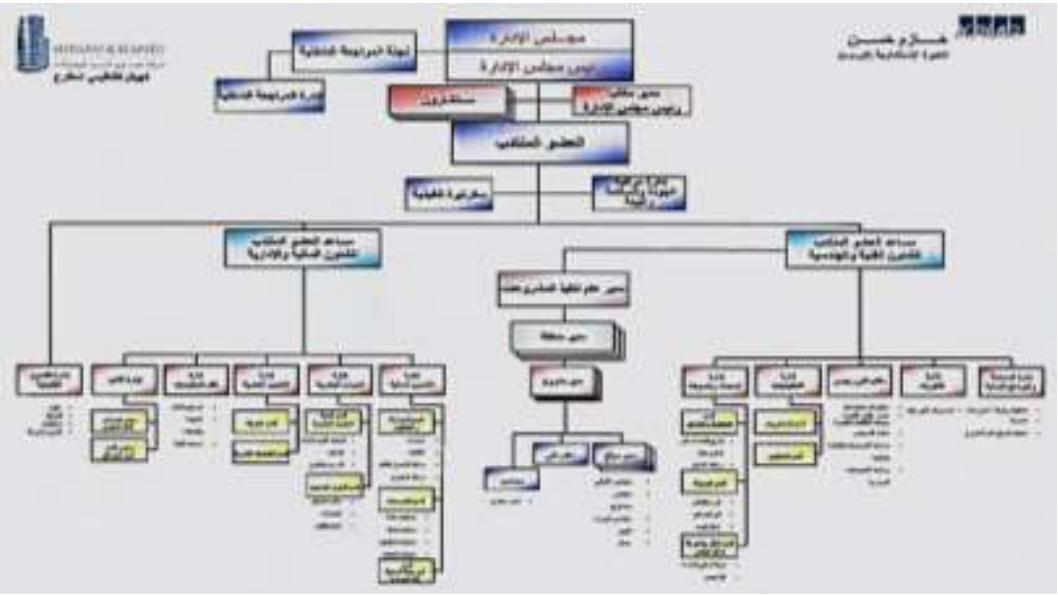

Fig. 10. Hossam \& El-Said Co. organizational structure (After Modification)

\begin{tabular}{|c|c|c|c|c|c|c|}
\hline Netrme Stutemem Dats & $\begin{array}{l}3122 x \\
\text { to } 000\end{array}$ & $\begin{array}{l}3420 \% \\
\text { kCP } 100\end{array}$ & $\begin{array}{l}\text { MV1206 } \\
\text { EGP } 000\end{array}$ & $\begin{array}{l}312200 \\
7 G 6000\end{array}$ & $\begin{array}{l}\text { tineso } \\
\operatorname{ten} \text { Do }\end{array}$ & 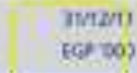 \\
\hline Net other income lespense) & $\{24,(41)$ & $\min$ & S67,456 & {$[195.167)$} & $(356,521)$ & $(653,063)$ \\
\hline Income before taxes & $3,549,587$ & $1,458,547$ & $4,574,591$ & $3,041,518$ & 4485,196 & $5,767,374$ \\
\hline Providon for noome tares & 136.378 & 92.036 & 65.841 & $\mid 291,3000$ & $(340,050)$ & $(1,555,895)$ \\
\hline Aisests from dscontnued operations & - & 2511.048 & 11,382 & -2 & $2=$ & 268.921 \\
\hline Gan on sale of cemet goep & -5 & $62,27,7202$ & $1,433,451$ & 20 & 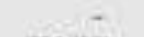 & 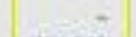 \\
\hline Mnerity etiment & 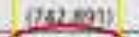 & $(051,367)$ & 036,24 : & 1311618 & $004 \times 491$ & 1451,545 \\
\hline Net income & (2.670.748) & 66.020 .974 & 5.365 .695 & 2.416 .600 & 2,34487 & 4.028.843) \\
\hline \multicolumn{7}{|l|}{ Marive informution } \\
\hline Ieninge per stume! & 1293 & 3270 & 2560 & 1174 & 16.21 & 1004 \\
\hline Cash devidend oer shane? & 500 & 305,00 & 31050 & 1002 & 1926 & $12.4 \%$ \\
\hline
\end{tabular}

Fig. 11. Orascom Co. financial situation 2006-2011

\subsection{Case (5): C5: Egyptian Dredgers Co.}

The Company was established in 1884 and it was nationalized in 1961. It was rated to first level with capital volume 48 million pounds [19]. Fig (12) shows the company's organizational structure "Traditional structure". Fig (13) shows a continuous decrease in the company's financial situation through $2008-2013$.

\subsection{Case (6):C6: El-Giza Co.}

Giza General Contracting Group is a full service contractor [20]. Fig (14) shows the company's organizational structure "Mixture between Matrix and Functional based on geographic location structure". A clear increase in the company's capital and profit i.e. the company's financial situation for years 2012 and 2013, as shown in Fig (15). 


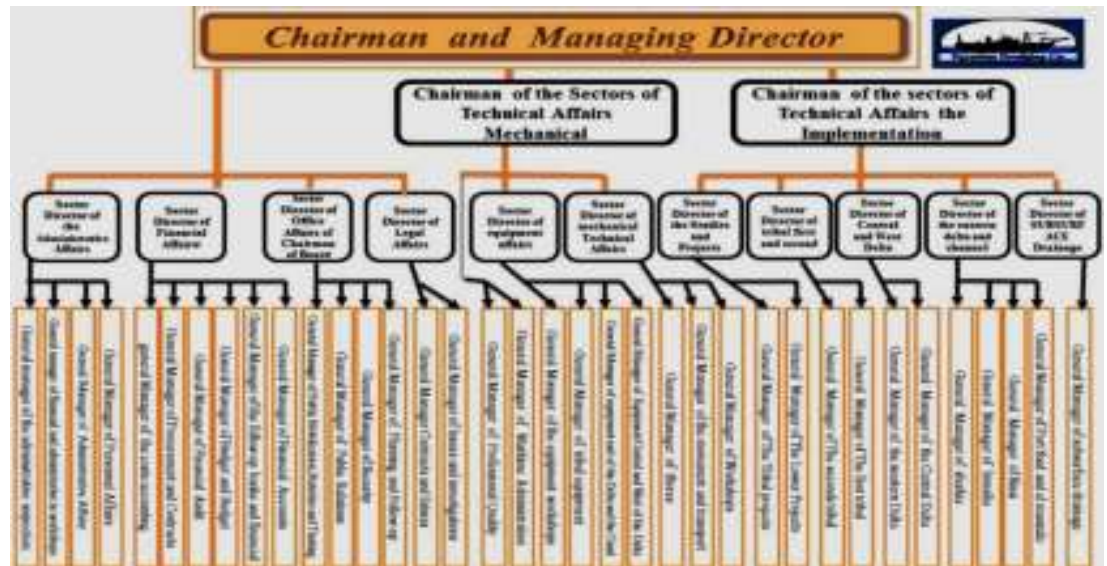

Fig. 12. Egyptian Dredgers Co. organizational structure

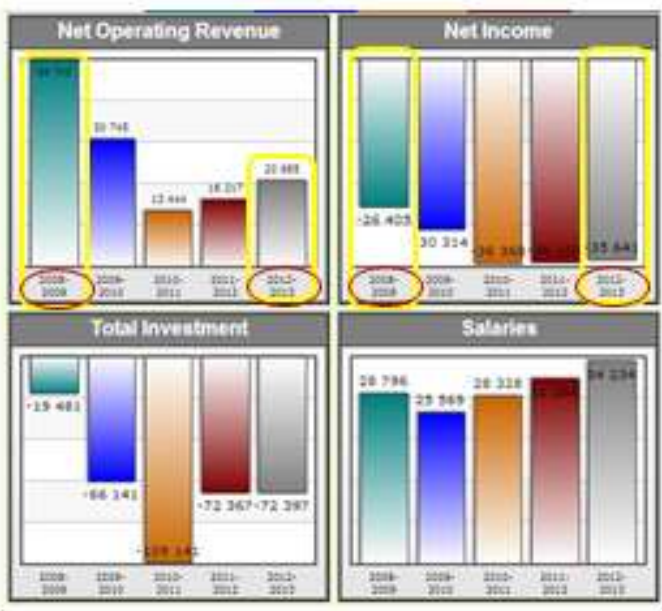

Fig. 13. Egyptian Dredgers Co. Financial situation 2008-2013

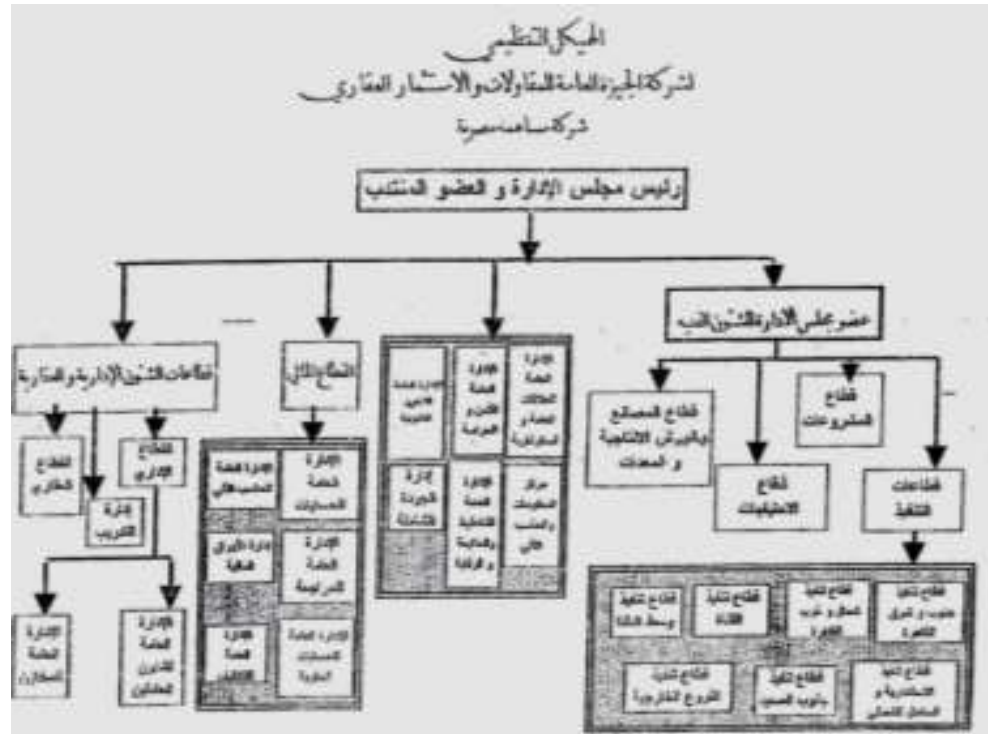

Fig. 14. Giza Co. organizational structure 


\subsection{Case (7): C7: El-Swedy Electric Co.}

El-Swedy Electric is a well-established group with extensive holdings, both locally and beyond borders in several other Middle Eastern \& African countries as well as some European \& Asian countries [21]. Fig (16) shows the company's organizational structure "Functional structure". While, the revenues and gross profit increases through the years 2009-2013 there is a noticeable decrease in the company's net profit, as shown in Fig (17).

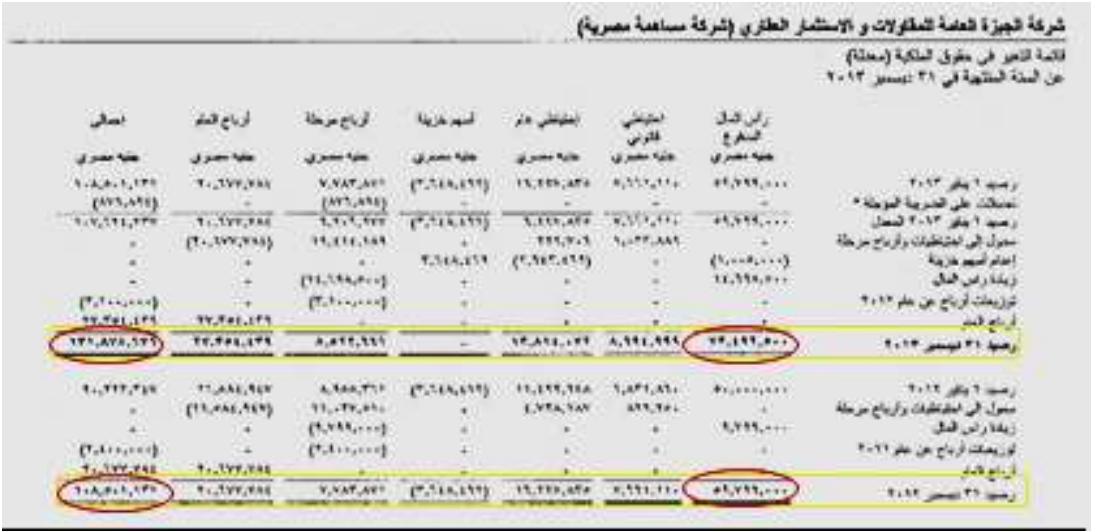

Fig. 15. Giza Co. financial situation 2012, 2013

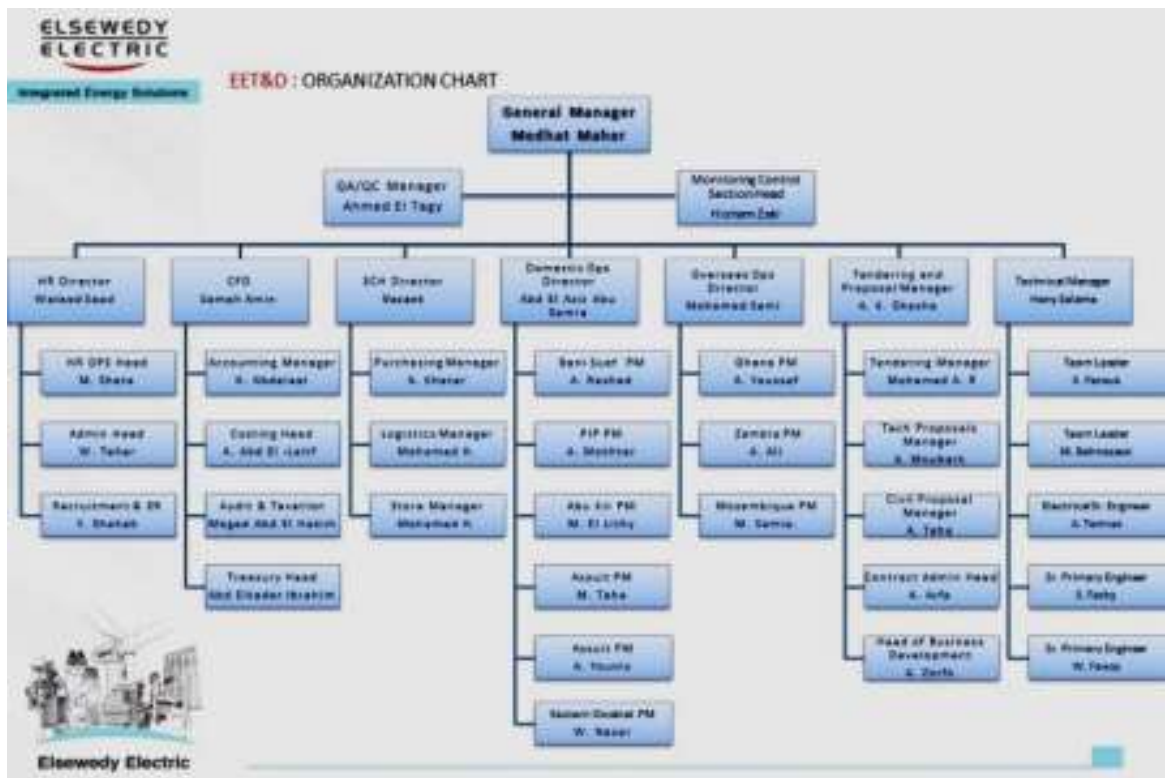

Fig. 16. El-Swedy Electric Co. organizational structure

\section{Statistical analysis and discussions}

Data was analyzed using SPSS version 16 and Microsoft Excel. The One-Way ANOVA Test was employed to determine the significance of the relationship. Results are represented in bar charts. Results are discussed and analyzed in the following sections. 


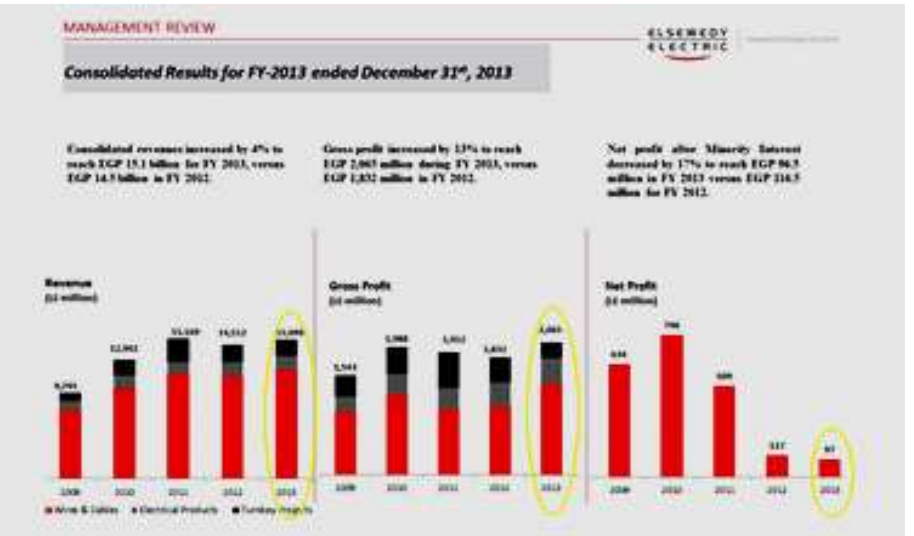

Fig. 17. El-Swedy Electric Co. financial status 2008-2013

\subsection{Group (A): Organization strategy, mission and values}

Questions of Group (A) investigate the companies' strategy, mission, and values and how much are they applicable and recognized by the company members. Results are shown in Table (6) and Figure (18). Results indicate that there is no significant difference in companies' answers for this group $(p<0.05)$. Almost, all companies agree for all questions, except for companies C5 and C7. From personal interviews it was noticed that, in public sector companies there is a clearly defined strategy, mission and values known and shared only by upper management which is probably due to the centralization of authority in these companies. However, in private and business sector companies although they might not have well-known, the company members are aware of its clearly defined strategy and find it applicable through work procedures. In these companies management ensures that employees feel they are effective members in the company performance.

Table 6.

One way Anova Test between groups for questions (A1-A7) of Group (A)

\begin{tabular}{|c|c|c|c|}
\hline Group (A) & $\begin{array}{l}\text { Sum of } \\
\text { Squares }\end{array}$ & $\begin{array}{c}\text { Mean } \\
\text { Square }\end{array}$ & Sig. \\
\hline A1: The organization has a clearly defined strategy. & 62.004 & 10.334 & .000 \\
\hline A2: The organization has clear and specific announced goals. & 63.634 & 10.606 & .000 \\
\hline $\begin{array}{l}\text { A3: A set of "business values" guide the organization in the way } \\
\text { it conducts its business. }\end{array}$ & 52.633 & 8.772 & .000 \\
\hline A4: The culture of my organization is intrinsically linked to these values. & 35.468 & 5.911 & .000 \\
\hline $\begin{array}{l}\text { A5: These values are known, shared and practiced by every member of } \\
\text { the organization. }\end{array}$ & 47.563 & 7.927 & .000 \\
\hline $\begin{array}{l}\text { A6: The business values and mission statement of my organization have } \\
\text { a positive impact on performance. }\end{array}$ & 41.710 & 6.952 & .000 \\
\hline $\begin{array}{l}\text { A7: Members in the organization who are found to be involved in } \\
\text { corruption are dealt with accordingly. }\end{array}$ & 61.742 & 10.290 & .000 \\
\hline
\end{tabular}

\subsection{Group (B): Managers performance and responsibilities}

Questions of Group (B) investigate the managers' performance, responsibilities and how much do they efficiently manage companies' employees and resources. Results are 
shown in Table (7) and Figure (19). Results indicate that there is high significant difference in companies' answers for questions (B1, B4) $(p>0.05)$ while, there is no significant difference in companies' answers for the other questions in this group ( $\mathrm{p}<$ 0.05). Almost, all companies agree for all questions, except for company C5 which disagree question B6. From the personal interviews it has been noticed that the success of any organizational structure depends basically on the C.E.O. regardless the organizational structure type. Centralization and narrow span of control are the main traits of most of the companies. Also, the limited authority given by some companies to the project managers could cause the stop of the work on a certain project for minor details. In Public sector companies, the work paper goes through a long series of due to long and wide organizational structure, which causes a great loss of time and money.

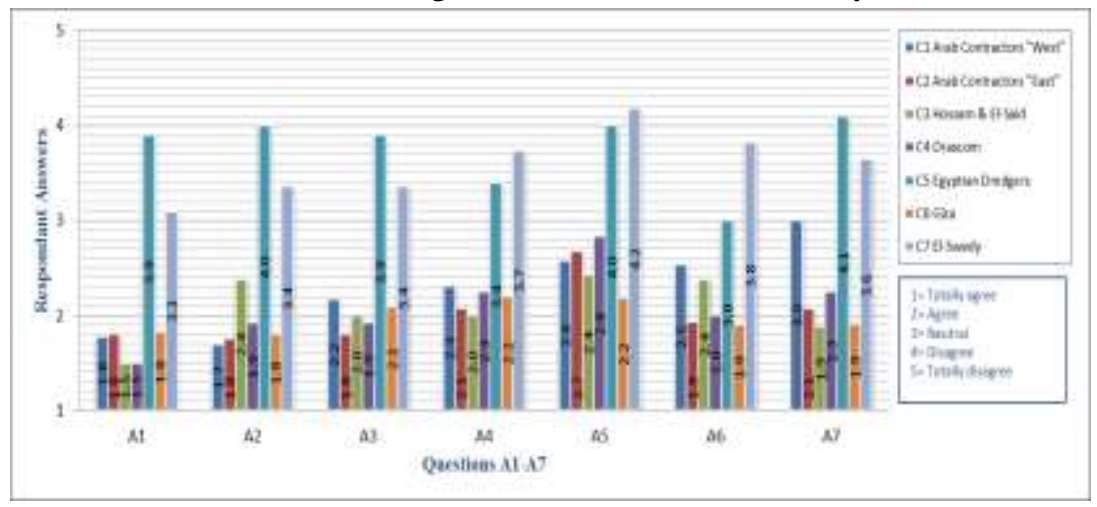

Fig. 18. Companies' answers for Group (A)

Table 7.

One way Anova Test between groups for questions (B1-B9)

\begin{tabular}{|l|c|c|c|}
\hline \multicolumn{1}{|c|}{ Group (B) } & $\begin{array}{c}\text { Sum of } \\
\text { Squares }\end{array}$ & $\begin{array}{c}\text { Mean } \\
\text { Square }\end{array}$ & Sig. \\
\hline $\begin{array}{l}\text { B1: The manager is responsible for selecting, obtaining, distributing, } \\
\text { organizing and putting to use all of the available resources that are } \\
\text { necessary to pursue and achieve the organization's objectives. }\end{array}$ & 12.556 & 2.093 & .019 \\
\hline $\begin{array}{l}\text { B2: The manager considers both the material and the human factors into } \\
\text { account when sounding decisions being made. }\end{array}$ & 17.322 & 2.887 & .003 \\
\hline $\begin{array}{l}\text { B3: The manager fosters self-discipline within the team by encouraging } \\
\text { its members to seek responsibility in running the group's affairs. }\end{array}$ & 18.925 & 3.154 & .003 \\
\hline $\begin{array}{l}\text { B4: The manager evokes loyalty from the team member by being fair in } \\
\text { all dealings with them concerning matters of rates of pay, bonus } \\
\text { payments, promotion, discipline, and work allocation. }\end{array}$ & 19.603 & 3.267 & .027 \\
\hline $\begin{array}{l}\text { B5: The manager realizes the improvements in the individual's mental, } \\
\text { physical, and social conditions. }\end{array}$ & 44.437 & 7.406 & .000 \\
\hline B6: The manager selects suitable subordinates. & 37.729 & 6.288 & .000 \\
\hline B7: The manager treats each individual according to his/her personal abilities. & 22.385 & 3.731 & .000 \\
\hline $\begin{array}{l}\text { B8: The manager establishes good communications with the } \\
\text { Upper management. }\end{array}$ & 26.045 & 4.341 & .000 \\
\hline B9: The manager establishes good communications with the lower management. & 29.651 & 4.942 & .000 \\
\hline
\end{tabular}




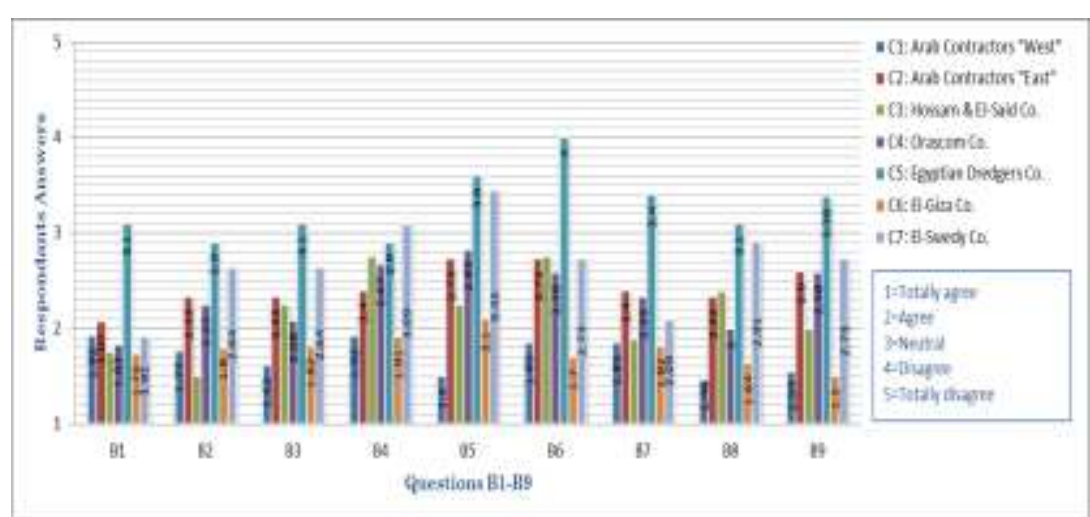

Fig. 19. Companies' answers for Group (B)

\subsection{Group $(C)$ : Employees performance and satisfaction}

Questions of Group (C) investigate the employees' performance, contribution, loyalty and how much are they satisfied about the company performance. Results are shown in Table (8) and Figure (20). Results indicate that there is high significant difference in companies' answers for questions (C5, C6) ( $\mathrm{p}>0.05)$; significant difference for the answers of question (C4) ( $\mathrm{p}=$ 0.05). While, there is no significant difference in companies' answers for the other questions in this group ( $\mathrm{p}<0.05)$. Almost, all companies agree for all questions, except for companies C5and C7 which disagree for questions (c1, c2, c3 and c7). From personal interviews, it has been noticed that currently in Egypt, recruitment is mostly based on favoritism and personal interests rather than qualification and experience. In private sector companies there is no clear job description for each job title, which causes confusion in employees' authorities and responsibilities. Employees in public sector companies don't feel free to express their dissatisfaction, for the fear of being blamed or worse. Elder employees are more loyal to their firms than younger ones. Business and private sector firms upgrade their employees and give them bonuses on a regular basis in a reasonable way based on reports of good work.

Table 8.

One way Anova Test between groups for questions (C1-C7)

\begin{tabular}{|c|c|c|c|}
\hline Group (C) & $\begin{array}{c}\text { Sum of } \\
\text { Squares }\end{array}$ & $\begin{array}{c}\text { Mean } \\
\text { Square }\end{array}$ & Sig. \\
\hline $\begin{array}{l}\mathrm{C} 1 \text { : The employees are consulted in respect of decisions regarding } \\
\text { what the organization plan to do }\end{array}$ & 44.070 & 7.345 & .000 \\
\hline $\begin{array}{l}\text { C2: Employees are encouraged to voice their technical opinions } \\
\text { without fear }\end{array}$ & 61.225 & 10.204 & .000 \\
\hline $\begin{array}{l}\text { C3: Employees are encouraged to share the responsibility of things } \\
\text { that go wrong in their work group }\end{array}$ & 38.495 & 6.416 & .000 \\
\hline C4: The performance appraisals are used as the basis to reward employees & 24.367 & 4.061 & .005 \\
\hline $\begin{array}{l}\text { C5: Employees accept criticism or negative feedback without } \\
\text { being defensive }\end{array}$ & 7.239 & 1.206 & .467 \\
\hline $\begin{array}{l}\text { C6: The organization emphasizes on team contributions rather } \\
\text { than individual contributions }\end{array}$ & 11.810 & 1.968 & .076 \\
\hline C7: The employees know what they need to do to succeed on the long run & 20.812 & 3.469 & .004 \\
\hline
\end{tabular}




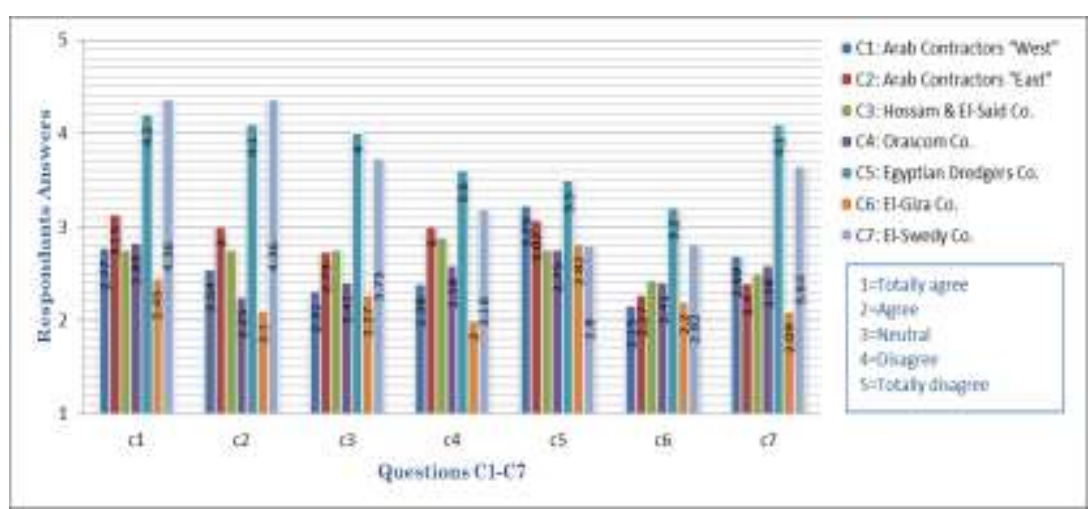

Fig. 20. Companies' answers for Group (C)

\subsection{Group (D): Dataflow evaluation}

Questions of Group (D) investigate the access to projects' database and its efficiency. Results are shown in Table (9) and Figure (21). Results indicate that there is high significant difference in companies' answers for question (D4) ( $p>0.05)$. While, there is no significant difference in companies' answers for the other questions in this group $(\mathrm{p}<$ 0.05). Almost, all companies agree for all questions, except for companies C5and C7 disagree for all questions. Through the personal interviews, there were complaints about limited access for projects' technical database which leads to repeating same mistakes in public sector companies.

Table 9.

One way Anova Test between groups for questions (D1-D4) for Group (D)

\begin{tabular}{|l|c|c|c|}
\hline \multicolumn{1}{|c|}{ Group (D) } & $\begin{array}{c}\text { Sum of } \\
\text { Squares }\end{array}$ & $\begin{array}{c}\text { Mean } \\
\text { Square }\end{array}$ & Sig. \\
\hline D1: Each project has a well-documented database. & 53.716 & 8.953 & .000 \\
\hline D2: All managers have access to projects' Technical and Financial database & 44.516 & 7.419 & .000 \\
\hline D3: All employees have access to projects' Technical database. & 27.694 & 4.616 & .006 \\
\hline D4: All employees have access to projects' Financial database. & 15.562 & 2.594 & .111 \\
\hline
\end{tabular}

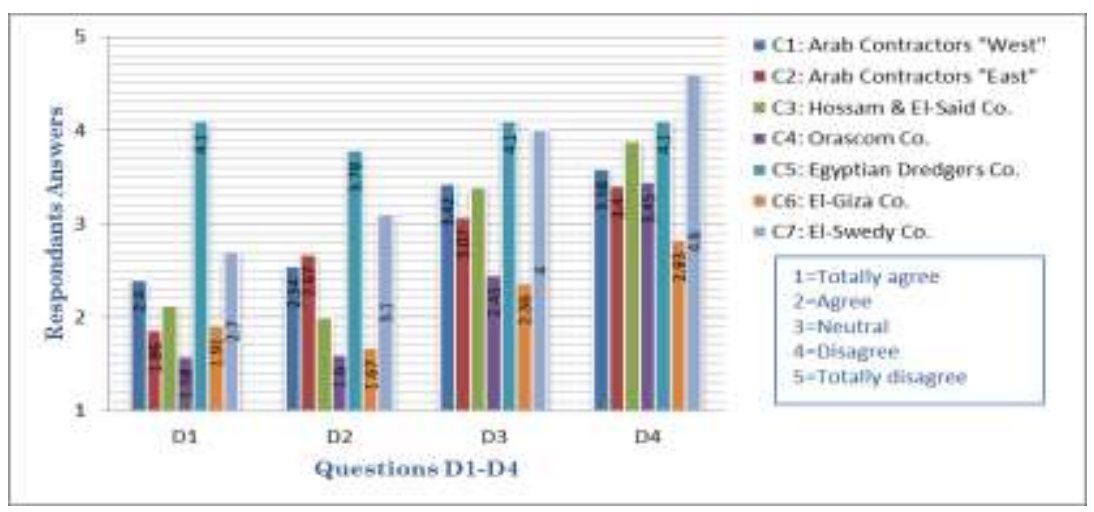

Fig. 21. Companies' answers for Group (D) 
Sara S. El-Khoriby, et al., analyzing organizational structure for contracting firms' of

\subsection{Group (E): Reporting process evaluation}

Questions of Group (E) investigate reporting process between the companies' different departments and the methods of evaluating employees. Results are shown in Table (10) and Figure (22). Results indicate that there is high significant difference in companies' answers for question (E2) ( $p>0.05$ ). While, there is no significant difference in companies' answers for the other questions in this group $(\mathrm{p}<0.05)$. Almost, all companies agree for all questions, except for company C5 tends to disagree for question E4. From personal interviews, it has been noticed that the contradiction between what really happens in the project field and what is written in reports delivered to higher management, causes a number of disputes that consumes the firm's money and time to solve it.

Table 10.

One way Anova Test between groups for questions (E1-E4)

\begin{tabular}{|l|c|c|c|}
\hline \multicolumn{1}{|c|}{ Group (E) } & $\begin{array}{c}\text { Sum of } \\
\text { Squares }\end{array}$ & $\begin{array}{c}\text { Mean } \\
\text { Square }\end{array}$ & Sig. \\
\hline $\begin{array}{l}\text { E1: Technical reports are sent on a regular basis from the project } \\
\text { field to the technical offices of the organization }\end{array}$ & 18.242 & 3.040 & .007 \\
\hline $\begin{array}{l}\text { E2: Employees' evaluation reports are sent on a regular basis } \\
\text { from the Managers/Leaders to the organization's quality } \\
\text { management department (C.E.O.). }\end{array}$ & 10.460 & 1.743 & .094 \\
\hline $\begin{array}{l}\text { E3: Work progress reports are sent on a regular basis from the } \\
\text { project managers to the C.E.O. and to organization's quality } \\
\text { management department }\end{array}$ & 16.965 & 2.827 & .004 \\
\hline $\begin{array}{l}\text { E4: When evaluating employees these factors are considered for each } \\
\text { employee (efficiency- effort expended - performance quality). }\end{array}$ & 29.452 & 4.909 & .000 \\
\hline
\end{tabular}

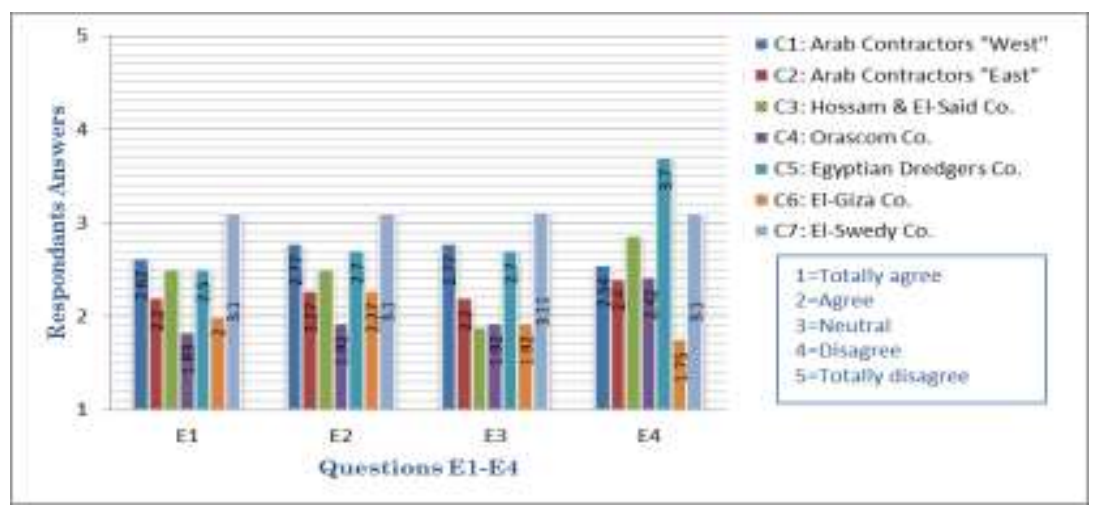

Fig. 22. Companies' answers for Group (E)

\subsection{Group $(F)$ : Innovation and training enhancement}

Questions of Group (F) investigate methods of training and developing employees. Results are shown in Table (11) and Figure (23). Results indicate that no significant difference in companies' answers for the questions in this group $(\mathrm{p}<0.05)$. Almost, all companies agree for all questions, except for companies C5 and C7. From personal interviews, it was found that only Arab Contractors Co. provides professional training on regular basis for its employees. 
However, it was noticed that some employees aren't interested in getting any professional training, they prefer to gain experience through work and from elder employees.

Table 11.

One way Anova Test between groups for questions (F1-F4) for Group (F)

\begin{tabular}{|l|c|c|c|}
\hline \multicolumn{1}{|c|}{ Group (F) } & $\begin{array}{c}\text { Sum of } \\
\text { Squares }\end{array}$ & $\begin{array}{c}\text { Mean } \\
\text { Square }\end{array}$ & Sig. \\
\hline F1: The organization provides adequate training to employees. & 30.938 & 5.156 & .000 \\
\hline F2: The employees are encouraged to be creative and innovative. & 34.577 & 5.763 & .000 \\
\hline $\begin{array}{l}\text { F3: The organization enhances competence in transforming } \\
\text { employees' innovative ideas into decisions. }\end{array}$ & 47.439 & 7.907 & .000 \\
\hline $\begin{array}{l}\text { F4: The employees are coached to improve their skills so they } \\
\text { can achieve higher levels of performance. }\end{array}$ & 47.779 & 7.963 & .000 \\
\hline
\end{tabular}

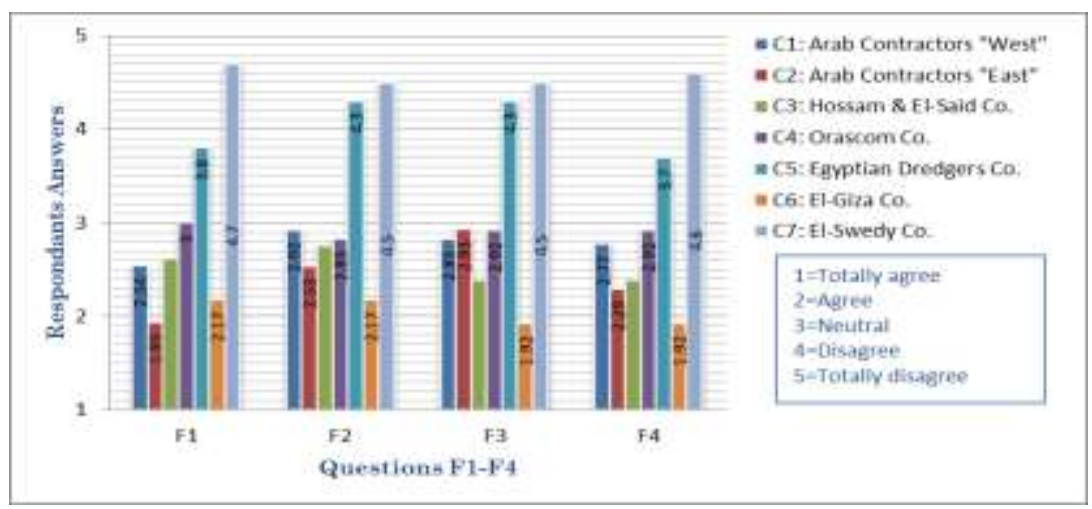

Fig. 23. Companies' answers for Group (F)

\subsection{Group $(G)$ : Organizations financial performance}

Questions of Group (G) investigate the organization financial performance, its effectiveness in achieving predetermined goals and its ability to develop and adopt according to labor market needs. Results are shown in Table (12) and Figure (24). Results indicate that no significant difference in companies' answers for the questions in this group ( $\mathrm{p}<0.05)$. Almost, all companies agree for all questions, except for companies C5 and C7. From personal interviews, it was clear that relatively few firms have the flexibility to change, update or modify their OS or strategic plan, to commensurate with the labor market changes. Moreover, it has been obvious that some firms practices quality control standards without having a certificate or a quality control department while other firms are considered overqualified for the market needs here in Egypt. However it costs the firm too much additional budget to maintain and keep this level of quality. Unfortunately, overqualified firms are being accepted technically, and rejected financially in bids and tenders now in Egypt. Obviously, public sector firms suffer more taxes and administrative fees than private sector firms do. Based on companies' timeline documents, the study found out that most of the contracting firms deliver projects beyond their time schedule, due to the delay in the clients' payments especially when the client is the government. Finally, there has been a noticeable lake of studies concerning the labor market status quo, 
Sara S. El-Khoriby, et al., analyzing organizational structure for contracting firms' of .............

competent firms, current and future industry possibilities and limitations, in most of the firms which weakens the companies' competency in the labor market.

Table 12.

One way Anova Test between groups for questions (G1-G8) for Group (G)

\begin{tabular}{|l|c|c|c|}
\hline \multicolumn{1}{|c|}{ Group (G) } & $\begin{array}{c}\text { Sum of } \\
\text { Squares }\end{array}$ & $\begin{array}{c}\text { Mean } \\
\text { Square }\end{array}$ & Sig. \\
\hline G1:The organization prefers to meet predetermined goals on quality level. & 33.243 & 5.540 & .000 \\
\hline G2: The organization prefers to meet predetermined goals on cost control. & 21.860 & 3.643 & .000 \\
\hline $\begin{array}{l}\text { G3: The organization enhances competence in maintaining the } \\
\text { process of achieving the predetermined goals. }\end{array}$ & 32.528 & 5.421 & .000 \\
\hline G4: The projects are delivered on or ahead of schedule. & 54.890 & 9.148 & .000 \\
\hline G5: The organization prefers to meet predetermined goals on profitability. & 31.523 & 5.254 & .001 \\
\hline G6: The organization prefers to meet predetermined goals on revenue growth. & 32.611 & 5.435 & .000 \\
\hline $\begin{array}{l}\text { G7: The organization prefers to meet predetermined goals on } \\
\text { increasing shareholders returns. }\end{array}$ & 19.253 & 3.209 & .005 \\
\hline G8: The organization maintains being competitive in the market. & 45.056 & 7.509 & .000 \\
\hline
\end{tabular}

\subsection{Group (H): Internal business processes}

Questions of Group $(\mathrm{H})$ investigate the companies' business current status quo. Results are shown in Table (13) and Figure (25). Results indicate that there is high significant difference in companies' answers for question (H4) $(\mathrm{p}>0.05)$ and significant for question (H3). While, there is no significant difference in companies' answers for the other questions in this group ( $\mathrm{p}<$ 0.05). Almost, all companies agree for all questions, except for company C3 tends to disagree for question $\mathrm{H} 1$ and $\mathrm{H} 2$. Also $\mathrm{C} 5$ answered by disagree for question H4. From personal interviews, it has been noticed that contracting firms in Egypt have been facing some financial problems such as: the delay of payments; overwhelming taxes; administrative fees and many governmental obstacles on starting new business or changing activity i.e. bureaucracy and red tape. Also, it was obvious that firms prefer to maintain or increase their projects regardless, how much is the volume of business or the expected profit. Based on companies' documents, almost all public sector companies' projects are delivered above budget. This happens due to the continuous change in the political and economic circumstances locally and internationally which affects the labor market and thus, affects the firms' performance.

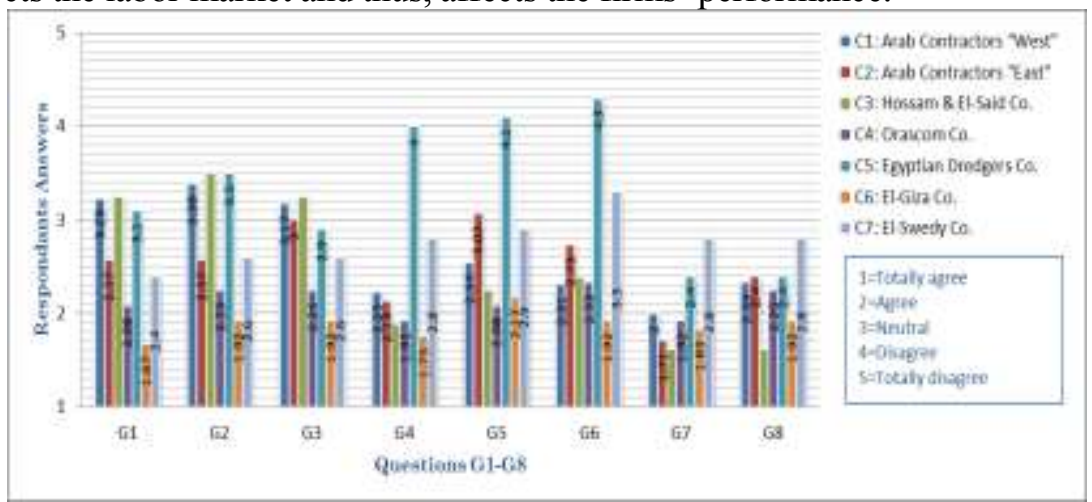

Fig. 24. Companies' answers for Group (G) 
JES, Assiut University, Faculty of Engineering, Vol. 43, No. 3, May 2015, pp. $403-428$

Table 13.

One way Anova Test between groups for questions (H1-H4) for Group (H)

\begin{tabular}{|l|c|c|c|}
\hline \multicolumn{1}{|c|}{ Group (H) } & $\begin{array}{c}\text { Sum of } \\
\text { Squares }\end{array}$ & $\begin{array}{c}\text { Mean } \\
\text { Square }\end{array}$ & Sig. \\
\hline H1: The projects are delivered on or under budget. & 37.464 & 6.244 & .000 \\
\hline H2: The organization achieves expected net profit. & 47.485 & 7.914 & .000 \\
\hline H3: The annual growth of the company depends on the volume of business. & 11.524 & 1.921 & .021 \\
\hline H4: The annual growth of the company depends on a number of projects. & 8.590 & 1.432 & .312 \\
\hline
\end{tabular}

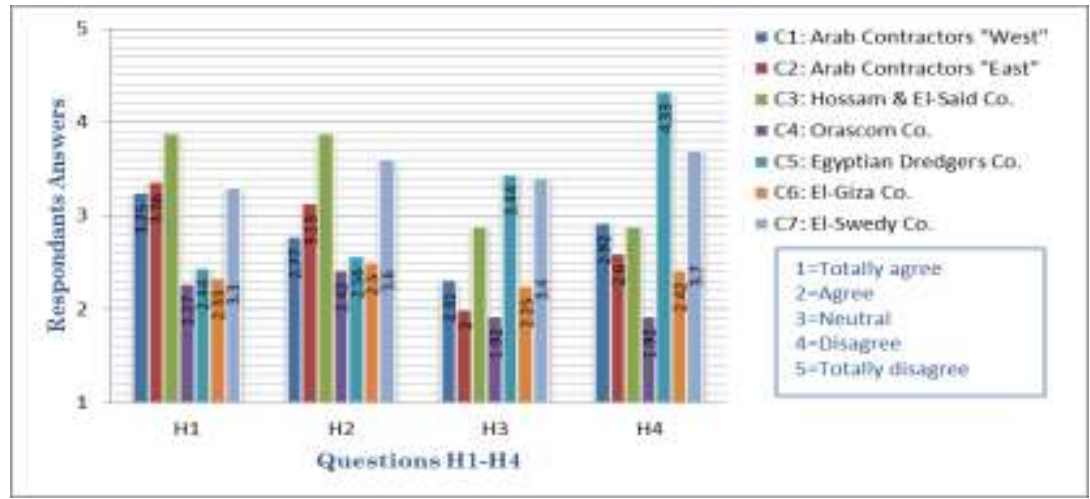

Fig. 25. Companies' answers for Group (H)

\subsection{Group (I): Research and development process}

Questions of Group (I) investigate the companies' Research and Development department role and efficiency. Results are shown in Table (14) and Figure (26). Results indicate insignificant difference in companies' answers for all questions $(p<0.05)$. Almost all companies agree for all questions, except for companies C5 and C7 disagree for all questions. Although most of the companies answered that the company has a separate department dedicated to the research and development studies (R \& D), there wasn't actually an (R \& D) dept. existing in either of them. Likely, answers to the rest of the questions are not realistic. This group of question shows that either the respondents were not interested in giving accurate answers. Or employees don't feel free to express their dissatisfaction even through survey questionnaires performed by their managers or other parties, for the fear of being blamed or worse. Also, it assures the ignorance of the (R \& D) dept. importance in these firms.

\section{Table 14.}

One way Anova Test between groups for questions (I1-I4) for Group (I)

\begin{tabular}{|l|c|c|c|}
\hline \multicolumn{1}{|c|}{ Group (I) } & $\begin{array}{c}\text { Sum of } \\
\text { Squares }\end{array}$ & $\begin{array}{c}\text { Mean } \\
\text { Square }\end{array}$ & Sig. \\
\hline I1: A separate department in my organization is dedicated to R \& D. & 77.144 & 12.857 & .000 \\
\hline I2: R \& D initiatives have a positive impact on the performance of the organization. & 66.807 & 11.135 & .000 \\
\hline I3: The organization invests heavily on R \& D. & 51.707 & 8.618 & .000 \\
\hline I4: R \& D ensures that the organization is on the cutting edge of the latest technology. & 63.695 & 10.616 & .000 \\
\hline
\end{tabular}




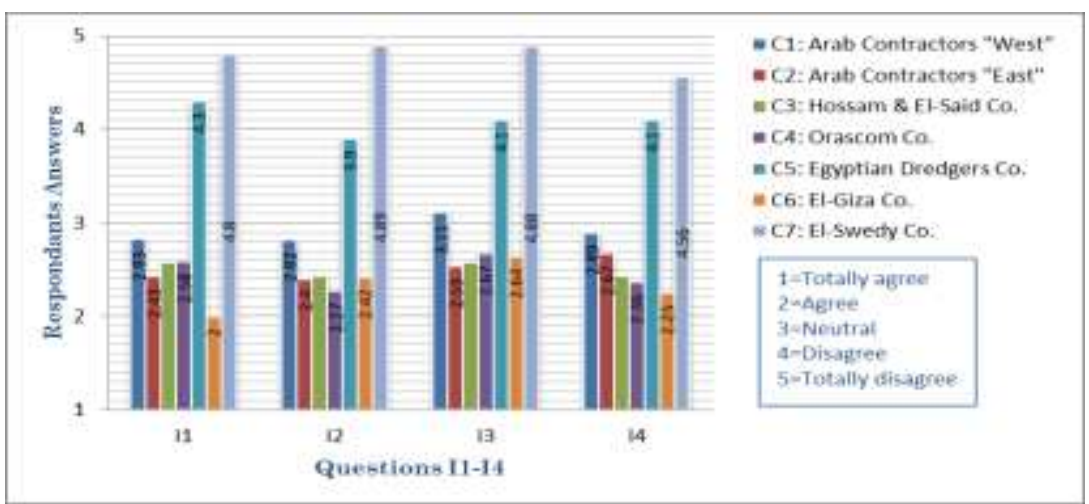

Fig .26. Companies' answers for Group (I)

\subsection{Group (J): Risk management awareness}

Questions of Group (J) investigate the companies' Risk Management department role and efficiency. Results are shown in Table (15) and Figure (27). Results indicate insignificant difference in companies' answers for all questions $(\mathrm{p}<0.05)$. Almost all companies agree for all questions, except for companies C5 and C7 disagree for all questions. Results from personal interviews, coincides with questionnaire results as, firms members' do recognize and apply the risk management standards.

\subsection{Group (K): Client/Customer satisfaction}

Questions of Group (K) investigate the companies' relationship with its customers. Results are shown in Table (16) and Figure (28). Results indicate insignificant difference in companies' answers for all questions $(\mathrm{p}<0.05)$. Almost all companies agree for all questions, except for companies C5 and C7 disagree for all questions. From personal interviews, it was found that current client preference contradicts with companies, strategies. As the current clients prefer lower project budget even if it means lower quality standard while, companies prefer to provide the highest level of quality regardless of the budget allocated.

Table 15.

One way Anova Test between groups for questions (J1-J5) for Group (J)

\begin{tabular}{|l|c|c|c|}
\hline Group $(\mathbf{J})$ & $\begin{array}{c}\text { Sum of } \\
\text { Squares }\end{array}$ & $\begin{array}{c}\text { Mean } \\
\text { Square }\end{array}$ & Sig. \\
\hline J1: Management in the organization understands and appreciates the value of RM. & 96.117 & 16.019 & .000 \\
\hline J2: RM helps the organization to minimize its risk exposure. & 74.449 & 12.408 & .000 \\
\hline J3: RM helps the organization compete effectively with other contractors. & 67.505 & 11.251 & .000 \\
\hline $\begin{array}{l}\text { J4: Effective RM has a positive impact on the performance of the organization. } \\
\text { J5: Employees in my organization understand and appreciate the } \\
\text { value of risk management. }\end{array}$ & 61.095 & 10.183 & .000 \\
\hline
\end{tabular}




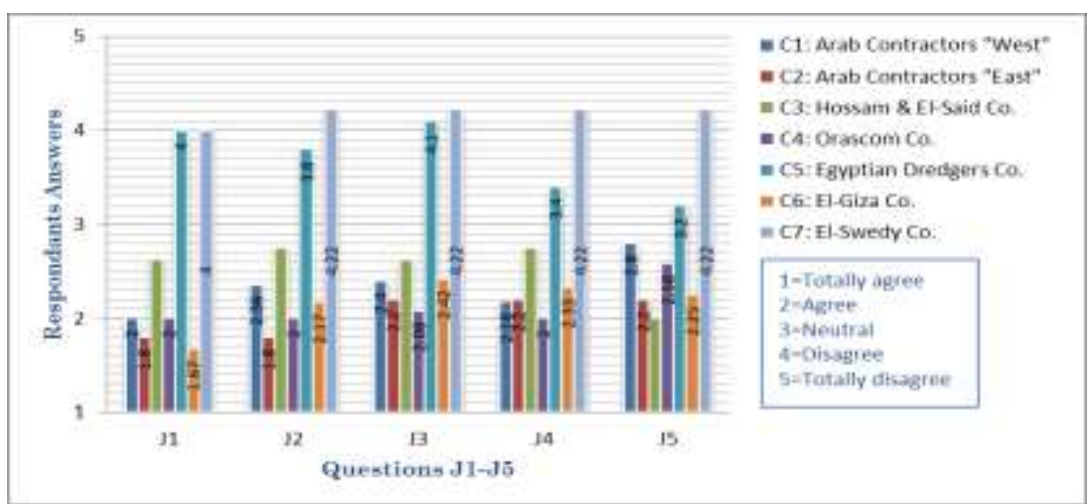

Fig. 27. Companies' answers for Group (J)

Table 16.

One way Anova Test between groups for questions (K1-K5) for Group (K)

\begin{tabular}{|l|c|c|c|}
\hline \multicolumn{1}{|c|}{ Group (K) } & $\begin{array}{c}\text { Sum of } \\
\text { Squares }\end{array}$ & $\begin{array}{c}\text { Mean } \\
\text { Square }\end{array}$ & Sig. \\
\hline K1: The organization enhances competence in satisfying customers' needs. & 53.081 & 8.847 & .000 \\
\hline K2: The organization enhances competence in keeping existing customers. & 52.716 & 8.786 & .000 \\
\hline K3: The organization meets goals on company vision about customer service & 16.118 & 2.686 & .060 \\
\hline $\begin{array}{l}\text { K4: The organization responds positively to opinions, criticism and } \\
\text { complaints from customers. }\end{array}$ & 45.900 & 7.650 & .000 \\
\hline $\begin{array}{l}\text { K5: Positive relationship between the customer and the company } \\
\text { has a positive impact on the company's performance }\end{array}$ & 27.397 & 4.566 & .003 \\
\hline
\end{tabular}

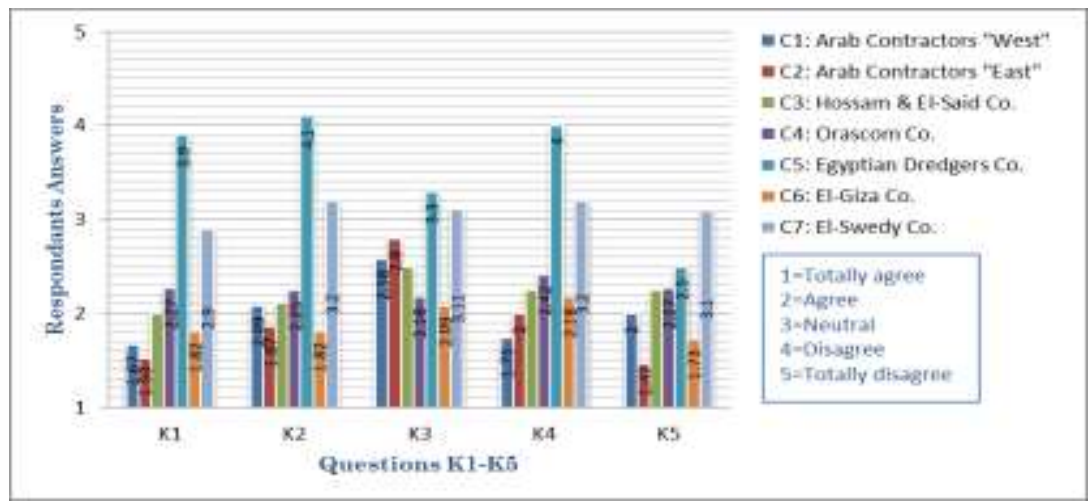

Fig. 28. Companies' answers for Group (K)

\section{Conclusion}

In contracting companies of classification "A", the organizational structure operates in its highest efficiency under some conditions such as hiring minimum number of most qualified personnel and avoiding centralization i.e. routine; bureaucracy and long paper work. While observing the seven companies' financial situation through years (20092013) and analyzing the questionnaire results, the study found that: 
1) Public sector companies achieved incensement in the profits in the international projects. On the contrary, there has been a decrease in the local projects' profits although it's using the same organizational structure.

2) The political circumstances has affected the labor market negatively, that lead to the same result on the companies in construction industry. But companies like Orascom, Giza and El-Swedy held their ground and didn't suffer sudden decrease in their capital, profits or projects' volume.

3) Also, employees in business and private sector companies have shown more loyalty to their companies. And had more freedom to express their opinions while filling the questionnaire.

4) Orascom and El-Giza companies, have shown more success in being stable, achieving goals and satisfying both customers and employees.

So, by considering the case of Hossam \& El-Said Co., which applied the Mixture between functional and matrix organizational structure when restructuring the company. Then, a composite structure between matrix and functional organizational structure based on (geographical location or project type), may be recommended as the optimal organizational structure for contracting firms class "A" in Egypt. Where, this composite structure determines clearly each employee's responsibilities and duties with an average span of control. Also, it provides the project manager enough authority to manage the project efficiently and deliver it on predetermined time and within specified budget thus, achieving company's goals.

\section{Recommendations}

1) Every firm should have a clear strategic plan and appropriate, flexible organizational structure which is compatible with the firm needs and could be easily updated or modified when needed.

2) Recruitment should be based on qualification and experience basis only, also there should be clear specific process of upgrade and bonuses based on progress reports.

3) It's important to generalize the use of the points system in the bids and tenders nowadays, so that firms of high quality standards do not suffer being rejected financially because of their high prices. Meanwhile, the firms could offer quality standards that commensurate with the size and budget of the project.

4) Also, In order to maintain delivering projects on time, project managers of preceding projects could be transferred to the delayed ones and vice-versa, so as all projects would be delivered within schedule.

5) Likely, Project managers should be granted more span of authority in making decisions and managing resources, to be able to deliver projects efficiently within time schedule.

6) Moreover, in order to come out of the recession state, firms could apply the "Mapping and Housing" strategy.

\section{REFERENCES}

[1] D.Wolf, "Execution and Structure," 2002. http://www.dewarsloan.com/workin\%20papersexecution\%20and20\%structure.html

[2] R. E. Walton, "A Vision-Led Approach to Management Restructuring," Organizational Dynamics, Vol. 14, No. 4, 1986, pp. 5-17.

[3] Mintzberg, H. (1983). Designing effective Organizations. Prentice-Hall, Inc. New Jersey. 
JES, Assiut University, Faculty of Engineering, Vol. 43, No. 3, May 2015, pp. 403 - 428

[4] E.C. Ubani, "Evaluating The Effects Of Organizational Structure On The Effective Delivery Of Civil Engineering Projects" , Interdisciplinary Journal Of Contemporary Research In Business, October 2012, Vol 4, No 6

[5] Q. Tran and Y. Tian, "Organizational Structure: Influencing Factors and Impact on a Firm," American Journal of Industrial and Business Management, Vol. 3 No. 2, 2013, pp. 229-236

[6] R. Underdown, “Organizational Structures," 2012. http://dept.lamar.edu/industrial/underdown/ org_mana/org/org_structure-George.html

[7] Patrick J. Montana, Bruce H. Charnov, "Management: Barron's business review series", Barron's, 1993

[8] Ganesh Vaidyanathan, "Project Management Process, Technology and Practice". Indiana University, 2013, Pearson

[9] Madison, D.L., Allen, R. W., Porter, L.W., Renwick, P.A., and Mayes, B.T. Organizational politics: An exploration of managers' perceptions. Human Relations, 1980, 33, 79-100; Finkelstien, S. Wby Smart Executives Fail: What You Can Learn From Them. Bergenfield, NJ: Penguin, 2003.

[10] Richard Germaina, Cindy Claycombb, Cornelia Drögec, "Supply chain variability, organizational structure, and performance: The moderating effect of demand unpredictability", Journal of Operations Management, Volume 26, Issue 5, September 2008, Pages 557-570.

[11] Chung-Jen Chena, Jing-Wen Huangb. "How organizational climate and structure affect knowledge management-The social interaction perspective", International Journal of Information Management, Volume 27, Issue 2, April 2007, Pages 104-118.

[12] Winfred Arthur Jr.a, Tobin B. Kyteb, Anton J. Villadoc, Curtis A. Morgand \& Stephen S. Roop, "Introducing a Subject Matter Expert-Based Utility Analysis Approach to Assessing the Utility of Organizational Interventions Such as Crew Resource Management Training", The International Journal of Aviation Psychology, Volume 21, Issue 2, 201.

[13] Yinghui B and Cheng. Eng G. (2004). The Impact of Organizational Structure on Project. Performance; html; (/F/ The \% 20 impact \% 20 Organizational \% Structure $\% 20$ Project \%.

[14] Sai On Cheung, Peter S. P. Wongab \& Anna L. Lam, "An investigation of the relationship between organizational culture and the performance of construction organizations". Journal of Business Economics and Management Volume 13, Issue 4, 2012. Pages 688-704.

[15] Kgositsile Samuel Sidumedi, "An Investigation into the Relationship between the Corporate Culture of South African Construction Firms and Performance". 2010

[16] Jim Clemmer 2013 , "The Leader's Digest: Timeless Principles for Team and Organization Success", Published by TCG Press.

[17] The Arab Contractors Osman Ahmed Osman \& Co., http://www.arabcont.com/English/about-us/overview.aspx

[18] Orascom construction industries, http://www.orascomci.com/index.php?id=home

[19] Egyptian Dredging Co., http://egyptian-dredging.com/Default_e.html

[20] Giza General Contracting And Real Estate Investment, http://www.algiza.com/IR.aspx?LID=6

[21] Elsewedy Electric Integrated Energy Solutions, http://www.elsewedyelectric.com/FE/Common/Showpage.aspx?Pageid=99\&g=6 
تحليل الهيكل الادارى التنظيمي لشركات المقاولات المصرية من الفئة "أ"

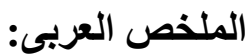

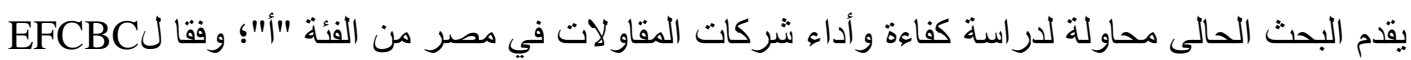

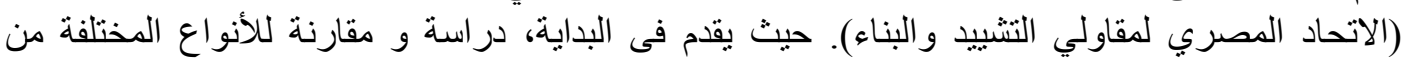

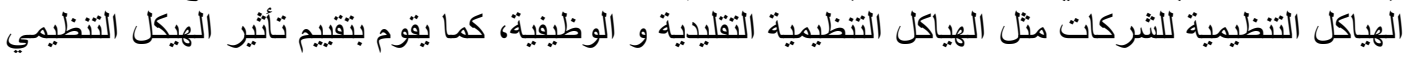

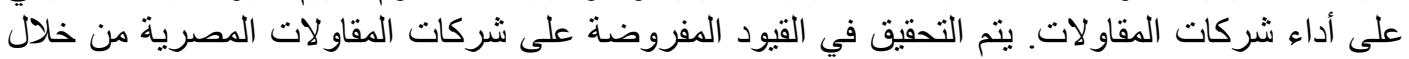

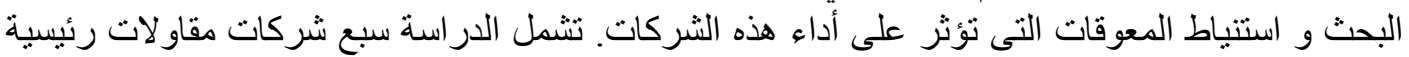

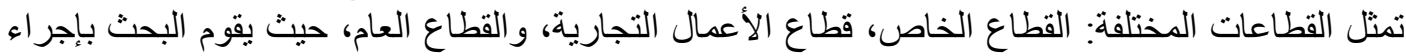

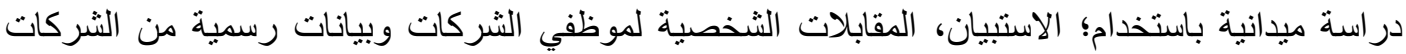

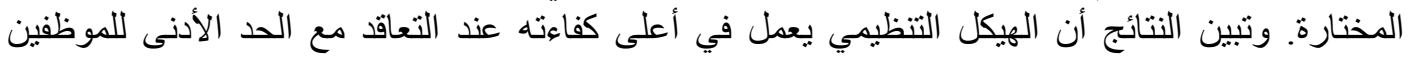

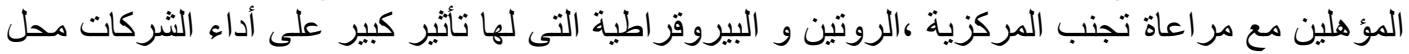

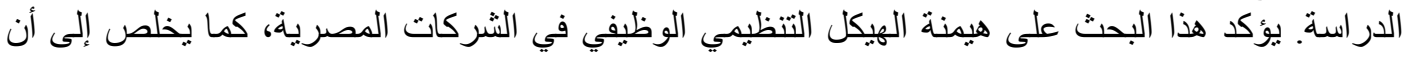

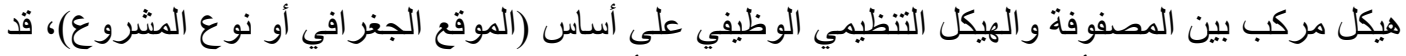

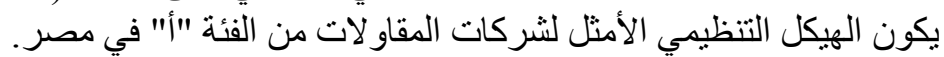

